\title{
Molecular Detection of the Causative Agent of Soft Rot (Pectobacterium carotovorum subsp carotovorum) in Banana (Musa sp.)
}

\author{
G. Ragavi ${ }^{1}$, M. Muthamilan ${ }^{1 *}$, S. Nakkeeran ${ }^{1}$, N. Kumaravadivel ${ }^{2}$, \\ U. Sivakumar ${ }^{3}$ and A. Suganthi ${ }^{4}$
}

${ }^{1}$ Department of Plant Pathology, CPPS, ${ }^{2}$ Department of Plant Molecular Biology and Bioinformatics, Centre for Plant Molecular Biology and Biotechnology, ${ }^{3}$ Department of Agricultural Microbiology, ${ }^{4}$ Department of Agricultural Entomology, TNAU, Coimbatore, India

*Corresponding author

\section{Keywords}

Banana (Musa sp), Pectobacterium carotovorum subsp. carotovorum, Soft rot

Article Info

Accepted:

12 October 2019

Available Online:

10 November 2019

\section{A B S T R A C T}

Soft rot disease of Banana caused by Pectobacterium carotovorum subsp. Carotovorum is found to be a serious disease and cause considerable yield loss. Common cultivars viz., Grand Naine, Rasthali and Nendran are extremely prone to this disease. Understanding the disease diagnosis and pathogen virulence is important in management programs. The pathogen was isolated from infected rhizomes from five locations of Theni district of Tamil Nadu. Pathogenicity of all isolates was confirmed by in vitro inoculation in rhizome bits and in vivo inoculation in pseudostems of three months old tissue cultured plants of cv. Grand Naine. The virulent isolates $\mathrm{Icb}_{4}$ and $\mathrm{Ikg}_{2}$ were characterized according to the morphological and microscopic characteristics, along with the physiological and biochemical assays; which indicates that the bacteria are gram negative, rod shaped, peritrichously flagellated. The colonies form characteristic deep cavities or pits in Crystal violet pectate medium (CVP). Results of biochemical tests showed that isolates $\mathrm{Icb}_{4}$ and $\mathrm{Ikg}_{2}$ have a positive reaction for catalase, $\mathrm{H}_{2} \mathrm{~S}$ production and nitrate reductase and a negative reaction for oxidase test, Indole test and gelatin liquefaction. The results determining the optimal temperature for the growth of isolates $\mathrm{Icb}_{4}$, and $\mathrm{Ikg}_{2}$ have revealed that the temperature at $30{ }^{\circ} \mathrm{C}$ $37{ }^{\circ} \mathrm{C}$ were suitable to obtain profuse growth of Pectobacterium. Total DNA extracted from the isolates $\mathrm{Icb}_{4}$, and $\mathrm{Ikg}_{2}$ were subjected to PCR analysis of $16 \mathrm{~S}$ 23S intergenic transcribed spacer region. PCR amplified $1.5 \mathrm{~kb}$ amplicons were sequenced. Sequence Homology and phylogeny analyses had shown that the isolates $\mathrm{Icb}_{4}$ and $\mathrm{Ikg}_{2}$ were belonged to Pectobacterium carotovorum subsp. carotovorum. 


\section{Introduction}

Banana (Musa sp) is one of the ancient cultivated tropical fruit crop in India next to mango in both area and production (d'Hont $e t$ al., 2012). Recently, rhizome rot or soft rot has come forth as a major disease, particularly in southern states of India (Usha, 2003; Snehalatharani and Khan, 2010; Nagaraj et al., 2012). Soft rot disease is cited as a major protective factor in tissue culture banana during the hardening phase and infield plants during the Post rainy season. The disease is incited by Pectobacterium carotovorum, a soil-borne pathogenic bacterium (Thangavelu, 2009). Currently, soft rot of banana is ahead importance in southern states of India (Snehalatharani and Khan, 2010) though earlier the disease was considered as of negligible importance. Accepted tissue culture banana cultivars Grand Naine and Nendran are susceptible to this disease. This disease is more pronounced in young suckers leading to soft rot accompanied by a bad tempered foul odour and rotting of the crown region followed by epinasty of leaves, which dry out abruptly. In the initial stage of infection, dark brown water soaked appearance in the cortex area. In advance stage, the internal lesions may rot to such extent that hollow space surrounded by dark soft tissues are formed and finally toppling over the plant (Nagaraj et al., 2012). Yeast Extract Glucose Calcium Carbonate (YGC) medium is a specific medium for Pectobacterium species; which produces acid. A clear zone surrounding each colony confirms from acid secretion, which releases the carbonate as carbon dioxide (Kado, 2006). Rapid and accurate diagnosis is essential for successful treatment and control of diseases. Diagnostic techniques of Erwinia spp. include the use of both traditional and modern molecular techniques. Different methods are followed in order to detect, identify and differentiate soft rot causing bacteria to species and subspecies level, of these methods: microscopy, isolation, biochemical characterization, serological techniques, pathogenicity and bioassay tests.

All of these methods are time consuming, insensitive, inaccurate and not suitable for routine work to test a large number of samples (Czajkowsk et al., 2009). In the last 30 years, Polymerase Chain Reaction (PCR) has been used for specific, rapid detection and identification of pathogen isolates. PCR techniques greatly enhance detection sensitivity, simplicity and rapidity compared with other methods of identification and are based on specific amplification of a target DNA sequence that is unique to a bacterial genome (Kang et al., 2003). The objective of the present study was to confirm the identity of Pectobacterium carotovorun subsp carotovorum as the causal organisms of soft rot of Banana through biochemical and molecular techniques.

\section{Materials and Methods}

\section{Source of bacterial strains}

Survey on the disease incidence was done to know the status of the disease in major banana growing areas of Theni district viz., Kamayagoundanpatti, Cumbum, Pudupatti, Erasakkanaickanur and Gokilapuram. Infected plant parts showing typical symptoms of soft rot disease of banana were collected from farmers' field at mentioned locations (Table 1). The survey is conducted by Rover's method. Per cent Disease Incidence (PDI) can be calculated by, Per cent disease incidence $=$ No. of plants infected/ Total No. of plants examined x 100. Soil type varied between sandy loam to laterite and the disease was observed mainly under conditions of high soil moisture and humidity. The affected rhizomes in the initial stages of rotting were collected in sterile polythene bags and brought to the laboratory for pathogen isolation (Fig. 1). 


\section{Isolation and maintenance of culture}

The affected part of the rhizome and pseudostem of banana was washed in the tap water, dried in blotter paper and then were cut into small pieces with a sterile scalpel and these were disinfected with 70 per cent alcohol for $45 \mathrm{sec}$ and washed thrice in sterile distilled water so as to remove traces of alcohol. The samples were dried by sterilized blotting paper. The small bit of sample was crushed in $5 \mathrm{ml}$ sterilized distilled water using sterilized mortar and pestle and kept for 15 minutes to come out bacterial ooze. CVP medium is the indicative media for Erwinia spp, so the pour plate method was done to get single colonies (Totagi, 2011). Isolated single colonies were picked and streaked on nutrient agar medium for developing pure cultures. The inoculated plates were incubated at $28^{\circ} \mathrm{C}$ for 48 hours. The pure cultures of the bacterial isolates were maintained in $70 \%$ glycerol stock in refrigerator at $-20^{0} \mathrm{C}$ for further studies

\section{Pathogenicity tests}

\section{In-vitro tests}

Healthy rhizome bits of banana variety 'Grand Naine' were surface sterilized in 70 per cent alcohol for $30 \mathrm{sec}$ and washed with double sterile water to wash excess alcohol and the rhizome bits were inoculated with $48 \mathrm{~h}$. old pathogenic bacteria culture under aseptic conditions (Rahman et al., 1994).

\section{In vivo tests}

The pseudostem of 60 days old tissue-cultured banana plants of cv. Grand Naine, were taken and make a small cut with help of a sterilized scalpel, after that the plants were inoculated with agar plugs contained $48 \mathrm{~h}$. old bacterial culture grown in NA medium and covered with sterile moist cotton (Thomas et al.,
2008). The pseudostem of Banana plants were inoculated with only agar plugs without any bacterial cultures served as control. The inoculated plants were kept in a glasshouse and were watered regularly. Observations were recorded for the development of symptoms such as pale yellow and brown discoloured necrotic leaves and the development of rotting at the rhizome region. Pathogen was reisolated from the infected rhizome and pseudostem samples and cultured in a specific CVP medium.

\section{Virulence test}

The virulence determination tests of bacterial isolates were determined by potato and carrot soft rot test with slight modifications by using a healthy potato and carrot. The potato and carrot were washed thoroughly in tap water, before being submerged in a container filled with $70 \%$ ethanol. After about two minutes they were removed, allowed to dry in the air, and cut these potato and carrot tubers into slices with a sterilized scalpel. The slices of potato and carrot placed in a sterilized Petri dish by inoculating with agar plugs contained $24 \mathrm{~h}$. old bacterial culture grown in NA medium and covered with sterile moist cotton and incubated at $30^{\circ} \mathrm{C}$. The observations were taken seven days after incubation. The rotting of potato and carrot tissue was an indication of the pectolytic activity (Perombelon, 1979; Pérombelon and Kelman, 1980). The pathogen was reisolated from the rotten potato and carrot slices and cultured in a specific medium.

\section{Bacterial characterization}

Characterization of bacterial pathogen was carried out by based on the virulence of pathogen on the rhizome, potato and carrot respectively, the highly virulent cultures of Pectobacterium carotovorum subsp carotovorum designated as isolates $\mathrm{Icb}_{4}$ and 
$\mathrm{Ikg}_{2}$ were Characterized by morphological, biochemical, physiological and molecular level (Snehalatharani and Khan, 2010).

\section{Cultural characterization}

Cultural Characterization was done on Nutrient Agar (NA) and Yeast Extract Glucose Calcium Carbonate (YGC) medium. Nutrient agar medium was prepared and streaked with a single colony of $48 \mathrm{~h}$. old bacterial culture and incubated at $28 \pm 1^{\circ} \mathrm{C}$ for $48 \mathrm{~h}$ (Snehalatharani and Khan, 2010). Yeast Extract Glucose Calcium Carbonate YGC medium was prepared and spot inoculated with $100 \mu \mathrm{l}$ of $24 \mathrm{~h}$. old bacterial culture and incubated at $28 \pm 1{ }^{\circ} \mathrm{C}$ for $48 \mathrm{~h}$ and observed for acid and carbon dioxide production (Kado, 2006; Snehalatharani and Khan, 2010).

\section{Morphological features of soft rot bacterium}

\section{General morphology}

The gram stain usually allowed observation of cell size, shape and arrangement.

\section{Gram staining (Skerman, 1967)}

A smear was prepared from a young $24 \mathrm{~h}$. old bacterial culture, air-dried and gently heat fix by lamp flaming on the underside of the slide. Slide was flooded with crystal violet for $1 \mathrm{~min}$ and washed for 3-4 seconds in a gentle flow of tap water. This was flooded with iodine solution for $1 \mathrm{~min}$ and washed again with tap water. The stain was decolourized by applying 95 per cent ethanol dropwise to smear until no more colour runs from the lower edge (usually 10-20 seconds). The slide was again washed and counterstained with safranin for $1 \mathrm{~min}$. the slide was again washed in tap water, air-dried and observed under oil immersion microscopy.

\section{Flagella staining}

The Leifson (1951) technique is used for flagella staining.

\section{Stain procedure}

The cleaned new slides were flamed and an area $2 / 3$ of the side was marked with a grease pencil. $24 \mathrm{~h}$. old young bacterial cultures were used. Sterilized distilled water was added gently on $24 \mathrm{~h}$. young bacterial slants and the motile bacteria were allowed to dispense in water.

A drop was placed on one edge of greased ring and tilt to allow a drop to glide downslide, air-dried without heat. Exactly 1 $\mathrm{ml}$ of Leifson stain was added to within the ring and stains for exactly $14 \mathrm{~min}$ and then washed with running tap water and air-dried. It was examined under oil immersion. Stain intensity may be varied by altering staining time.

\section{Biochemical characterization}

The physiological and biochemical characteristics of strain $\mathrm{Icb}_{4}$ and $\mathrm{Ikg}_{2}$ were studied for pectate degradation, gelatin liquefaction, urease production, $\mathrm{H}_{2} \mathrm{~S}$ production, nitrate reductase, sensitivity to erythromycin, Motility test, catalase, oxidase test, indole test methyl red test, Gelatin liquefaction, Caesin hydrolysis, growth at 3\% $\mathrm{NaCl}$ and Growth at 5\% NaCl (Table 4). The tests were conducted as per the methods described by Ploetz et al., (2003), Seo et al., (2002) and Fiori et al., (2005).

\section{Growth rate of bacteria at different temperatures}

Bacterial colonies (48 h. old) were inoculated into sterile nutrient broth in an Oakridge tube and incubated for $48 \mathrm{~h}$. at different 
temperatures $27,29,31,33,35,37$ and $39^{\circ} \mathrm{C}$, with shaking at $120 \mathrm{rpm}$ (Shrestha et al., 2005). Control was maintained using nutrient broth with no bacterial inoculation. Observations on optical density at $620 \mathrm{~nm}$ were read after 24 and $48 \mathrm{~h}$.

\section{Molecular characterization}

DNA was isolated from the bacterial cultures $\left(\mathrm{Icb}_{4}\right.$ and $\mathrm{Ikg}_{2}$ ) using lysis method (Chen and Kuo, 1993) and the 16S rRNA gene was amplified through Polymerase chain reaction (PCR) using the universal 16S rRNA primer set $27 \mathrm{~F}$ and $1492 \mathrm{R}$ (Meng et al., 2017).

PCR was performed using $50 \mu \mathrm{l}$ reaction mix containing $2 \mu 1$ of each primer, $25 \mu 1$ of master mix (Genei), $19 \mu \mathrm{l}$ of $\mathrm{H}_{2} \mathrm{O}$ and $2 \mu \mathrm{l}$ of DNA template $(5 \mu \mathrm{g} / \mu \mathrm{l})$.

Thermal cycler (Eppendorf Master cycler) included initial denaturation at $95{ }^{\circ} \mathrm{C}$ for $3 \mathrm{~min}$ followed by 35 cycles of denaturation at $94{ }^{\circ} \mathrm{C}$ for $1 \mathrm{~min}$, primer annealing at $60{ }^{\circ} \mathrm{C}$ for $1 \mathrm{~min}$ and primer extension at $72{ }^{\circ} \mathrm{C}$ for $1 \mathrm{~min}$ and final extension was at $72{ }^{\circ} \mathrm{C}$ for $10 \mathrm{~min}$.

The PCR products were electrophoresed and separated on $1.2 \%$ agarose gel and photographic using image analyser. The 1.5 Kbp PCR products were gel eluted using the QIAGEN gel extraction kit and sequenced at Eurofins Genomics. The Phylogenetic tree was constructed using MEGA 6.0 software. The bacterial isolates $\mathrm{Icb}_{4}$ and $\mathrm{Ikg}_{2}$ were used as reference out group.

\section{Statistical Analysis}

Mean differences of the disease incidence were evaluated with ANOVA using Duncan's Multiple Range-Test at 5\% significance (Gomez and Gomez, 1984). All the data were statistically analyzed with SPSS software and consequently interpreted.

\section{Results and Discussion}

Survey and isolation of the pathogen from Banana

Roving survey was conducted during 2017 to assess the disease incidence of soft rot of banana in Theni districts (Table 1). The per cent disease incidence was noticed in all the locations surveyed, with a range from 32.4 to 62.6 per cent. The maximum disease incidence was observed in Cumbum taluk followed by Kamayagoundanpatti village. The survey is in line with the studies conducted by Snehalatharani (2001) and Nagaraj and Khan (2002). Similarly, Thammaiah et al., (2005) and Vasundhara and Thammaiah, (2017) were conducted Roving survey major banana growing areas of Belgaum, Bagalkot and Bijapur districts of Northern Karnataka during 2012.

The causal organism Pectobacterium carotovorum subsp. carotovorum was isolated from infected rhizome and pseudostem showing characteristic symptoms of soft rot. Pathogen isolated from the infected samples have given small bacterial colonies on the NA medium, which were cream to white colour, to some extent raised and mucoid with a diameter of $2 \mathrm{~mm}$. Previously Snehalatharani and Khan (2010) and Totagi (2012) have reported the colony characters of Erwinia carotovora subsp carotrovora (Pectobacterium carotovorum). CVP medium, which is specific for Pectobacterium sp, characteristic small pits were formed.

\section{Pathogenicity and virulence test}

The results of Pathogenicity revealed that all the bacterial isolates were produced characteristics symptom of soft rot upon artificial inoculation. Rotting of inoculated rhizome bits of banana cv. Grand Naine was observed in 7 days under in-vitro condition the 
pathogen was reisolated in NA medium and CVP medium and produced characteristic pits similar to the original isolates. Usha (2003) also reported that the inoculated rhizome bits under artificial conditions produce rotting, discolouration and foul smell after 7 and 8days of inoculation, respectively.

Under in vivo condition, the bacterium has produced symptoms on tissue culture plants, 6 days after inoculation. Symptoms observed were yellowing of lower leaves and the yellowing gently spread to upper leaves. Deteriorating of the pseudostem has started and finally the plant chop down as the pseudostem got entirely rotten and emitted foul smell, after 16 days of inoculation.

Nagaraj et al., (2012) and Nagrale et al., (2013) reported that complete rotting of healthy rhizome bits were observed after 37 DAI under in vivo condition. The similar plant symptoms were observed by Thomas et al., (2008) who demonstrated that plants inoculated with pathogenic Pectobacterium carotovorum subsp. carotovorum produced rotting symptoms within 7-12 days after inoculation. Deviation was observed in days taken for the complete rotting of grand naine plants by different isolates. The minimum time taken for rotting was 4- 7 days by the isolate no. $\mathrm{Icb}_{4}$ and $\mathrm{Ikg}_{2}$ followed by $8-10$ days by $\mathrm{Ipp}_{6}$ and $\mathrm{Ien}_{11}$. Maximum time of 1012 days was taken by $\operatorname{Igp}_{9}$ (Table 2).

The results of virulence determination revealed that potato and carrot slices were inoculated with bacterial strains has been produced rotting symptoms with the emission of characteristic foul smell after 2-7days (Table 3), respectively. In similar studies, potato inoculated with bacterial pathogen produced the soft rot symptom after 3 days of inoculation (Togashi, 1988; Nabhan et al., 2006). Variation was observed in time for the rotting of potato and carrot by different isolates. Bacterial isolates $\mathrm{Ikg}_{2}$ and $\mathrm{Icb}_{4}$ recorded a minimum of 3 days for complete rotting of potato. Maximum time of 4-5 days by isolates $\operatorname{Ipp}_{6} \operatorname{Igp}_{9}$, and $\operatorname{Ien}_{11}$ respectively (Table 3). Minimum time taken for complete rotting was 4 days in carrot by isolates $\mathrm{Ikg}_{2}$ and $\mathrm{Icb}_{4}$. Whereas, maximum time taken for complete rotting of carrot was 5 and 7 days by Ipp $_{6} \operatorname{Igp}_{9}$, and $\operatorname{Ien}_{11}$, (Table 3). Rotting in carrot was slow and complete rotting was observed after 14 days after inoculation (Schillingford, 1974; Doolotkeldieva et al., 2016).

\section{Cultural characterization}

In YGC medium, Creamish yellow-coloured colonies were produced with a clear zone after $24 \mathrm{~h}$ of incubation. Small bubbles were observed on the apex of each bacterial colony due to the emission of carbon dioxide from the medium which is the characteristic feature of Pectobacterium carotovorum. Similarly, Usha (2003) has reported the cultural characters of Pectobacterium carotovorum in the YGC medium. Kim et al., (2012) stated that Pectobacterium and Erwinia strains were incubated on nutrient agar (NA) and Xanthomonas strains were grown on YGC medium.

\section{Morphological, biochemical and physiological characterization}

The Gram staining is the first step in the preliminary identification of a bacterial organism. While Gram staining is a priceless analytic tool in research settings, not all bacteria can be classified by this method. It is used to discriminate and categorize bacterial species into two great groups (Gram positive and Gram negative). In the present study after Gram staining, red colored short rods were observed under an oil immersion microscope, indicative of the Gram-negative nature of this bacterium. 
Table.1 Survey on disease incidence of soft rot of banana in Theni district of Tamil Nadu

\begin{tabular}{|c|c|c|c|c|c|}
\hline S. No & Isolate no & Place of collection & Districts & $\begin{array}{c}\text { GPS Data of } \\
\text { location in Latitude } \\
\text { - longitude }\end{array}$ & $\begin{array}{c}\text { Disease } \\
\text { incidence } \\
(\%)^{*}\end{array}$ \\
\hline 1. & $\mathrm{Ikg}_{2}$ & Kamayagoundanpatti & Theni & “9. 71-77.33” & $\begin{array}{c}54.1 \\
(47.35)\end{array}$ \\
\hline 2. & $\mathrm{Icb}_{4}$ & Cumbum & Theni & “9.68- 77.24" & $\begin{array}{c}62.6 \\
(52.3)\end{array}$ \\
\hline 3. & $\mathrm{Ipp}_{6}$ & Pudupatti & Theni & "9.76-77.30" & $\begin{array}{c}40 \\
(39.23)\end{array}$ \\
\hline 4. & $\operatorname{Igp}_{9}$ & Gokilapuram & Theni & “9.78-77.34" & $\begin{array}{c}36.9 \\
(37.41)\end{array}$ \\
\hline 5. & $\operatorname{Ien}_{11}$ & Erasakkanaickanur & Theni & “9.78-77.39" & $\begin{array}{c}32.4 \\
(34.70)\end{array}$ \\
\hline \multicolumn{4}{|c|}{$\mathrm{CD}(\mathrm{p}=0.05)$} & & 2.67 \\
\hline
\end{tabular}

Table.2 Period of development of symptoms in banana (cv. Grand Naine) plants

\begin{tabular}{|c|c|c|c|c|}
\hline S. No & Isolate no & $\begin{array}{c}\text { Yellowing of leaf } \\
\text { and rotting (days) }\end{array}$ & $\begin{array}{c}\text { Full rotting of } \\
\text { the plant (days) }\end{array}$ & $\begin{array}{c}\text { Falling down of plants } \\
\text { (days) }\end{array}$ \\
\hline $\mathbf{1 .}$ & $\mathrm{Ikg}_{2}$ & 5 & 6 & 7 \\
\hline $\mathbf{2 .}$ & $\mathrm{Icb}_{4}$ & 4 & 5 & 6 \\
\hline $\mathbf{3 .}$ & $\mathrm{Ipp}_{6}$ & 8 & 9 & 10 \\
\hline $\mathbf{4 .}$ & $\mathrm{Igp}_{9}$ & 10 & 11 & 12 \\
\hline $\mathbf{5 .}$ & $\mathrm{Ien}_{11}$ & 6 & 7 & 8 \\
\hline
\end{tabular}

Table.3 Virulence determinants of Pectobacterium carotovorum subsp. carotovorum by potato and carrot soft rot test

\begin{tabular}{|c|c|c|c|c|c|}
\hline \multirow{2}{*}{ S. No } & \multirow{2}{*}{ Isolates } & \multicolumn{2}{|c|}{ Potato soft rot } & \multicolumn{2}{c|}{ Carrot soft rot } \\
\cline { 3 - 6 } & & $\begin{array}{c}\text { Initiation of } \\
\text { rotting }\end{array}$ & $\begin{array}{c}\text { Completion of } \\
\text { rotting }\end{array}$ & $\begin{array}{c}\text { Initiation of } \\
\text { rotting }\end{array}$ & $\begin{array}{c}\text { Completion } \\
\text { of rotting }\end{array}$ \\
\hline $\mathbf{1 .}$ & $\mathbf{I k g}_{\mathbf{2}}$ & 2 & 3 & 2 & 4 \\
\hline $\mathbf{2}$ & $\mathbf{I c b}_{\mathbf{4}}$ & 2 & 3 & 2 & 4 \\
\hline $\mathbf{3}$. & $\mathbf{I p p}_{\mathbf{6}}$ & 3 & 4 & 3 & 5 \\
\hline $\mathbf{4}$ & $\mathbf{I g p}_{\mathbf{9}}$ & 4 & 5 & 4 & 6 \\
\hline $\mathbf{5 .}$ & Ien $_{\mathbf{1 1}}$ & 3 & 5 & 3 & 7 \\
\hline
\end{tabular}


Table.4 Morphological, physiological and biochemical characterization of soft rot causing virulent bacterial strains

\begin{tabular}{|c|c|c|c|}
\hline \multirow[t]{2}{*}{ S.No } & \multirow[t]{2}{*}{ Characteristics features } & \multicolumn{2}{|c|}{ Pectobacterium carotovorum subsp. carotovorum } \\
\hline & & $\mathbf{I c b}_{4}$ & $\mathbf{I k g}_{2}$ \\
\hline 1. & Colony character & $\begin{array}{l}\text { cream to yellowish color, } \\
\text { slightly raised and mucoid }\end{array}$ & $\begin{array}{l}\text { cream to yellowish color, } \\
\text { slightly raised and mucoid }\end{array}$ \\
\hline 2. & Gram reaction & - & - \\
\hline 3. & Pectate degradation & + & + \\
\hline 4. & $\begin{array}{l}\text { Pits formation on CVP } \\
\text { medium }\end{array}$ & + & + \\
\hline 5. & Flagella & Peritrichous & Peritrichous \\
\hline 6. & Growth at $36-37^{\circ} \mathrm{C}$ & + & + \\
\hline 7. & $\begin{array}{c}\text { Growth in presence of } 5 \% \\
\text { and } 3 \% \mathrm{NaCl}\end{array}$ & + & + \\
\hline 8. & Motility test & + & + \\
\hline 9. & Urease production & - & - \\
\hline 10. & Nitrate reductase & + & + \\
\hline 11. & $\mathrm{H}_{2} \mathrm{~S}$ production & + & + \\
\hline 12. & Catalase test & + & + \\
\hline 13. & Oxidase test & - & - \\
\hline 14. & Indole test & - & - \\
\hline 15. & Gelatin liquefaction & - & - \\
\hline 16. & Methyl red test & + & + \\
\hline 17. & Casein hydrolysis & + & + \\
\hline 18. & $\begin{array}{l}\text { Erythromycin sensitivity } \\
(200 \mathrm{ppm})\end{array}$ & + & + \\
\hline
\end{tabular}

Table.5 Effect of different temperature on growth of bacterial strains under in vitro

\begin{tabular}{|c|c|c|c|}
\hline \multirow{2}{*}{ S. No. } & \multirow{2}{*}{ Temperature $\left({ }^{\circ} \mathbf{C}\right)$} & \multicolumn{2}{|c|}{ OD value at 620 nm* } \\
\cline { 3 - 4 } & & Strain I $\left(\mathrm{Icb}_{4}\right)$ & Stain II $\left(\mathrm{Ikg}_{2}\right)$ \\
\hline $\mathbf{1}$ & 27 & 0.587 & 0.542 \\
\hline $\mathbf{2}$ & 29 & 0.668 & 0.652 \\
\hline $\mathbf{3}$ & 31 & 0.709 & 0.737 \\
\hline $\mathbf{4}$ & 33 & 0.819 & 0.885 \\
\hline $\mathbf{5}$ & 35 & 0.931 & 0.988 \\
\hline $\mathbf{6}$ & 37 & 1.465 & 1.204 \\
\hline $\mathbf{7}$ & 39 & 0.435 & 0.445 \\
\hline $\mathbf{8}$ & 40 & 0.157 & 0.164 \\
\hline
\end{tabular}


Fig.1 Symptoms of rhizome rot of banana
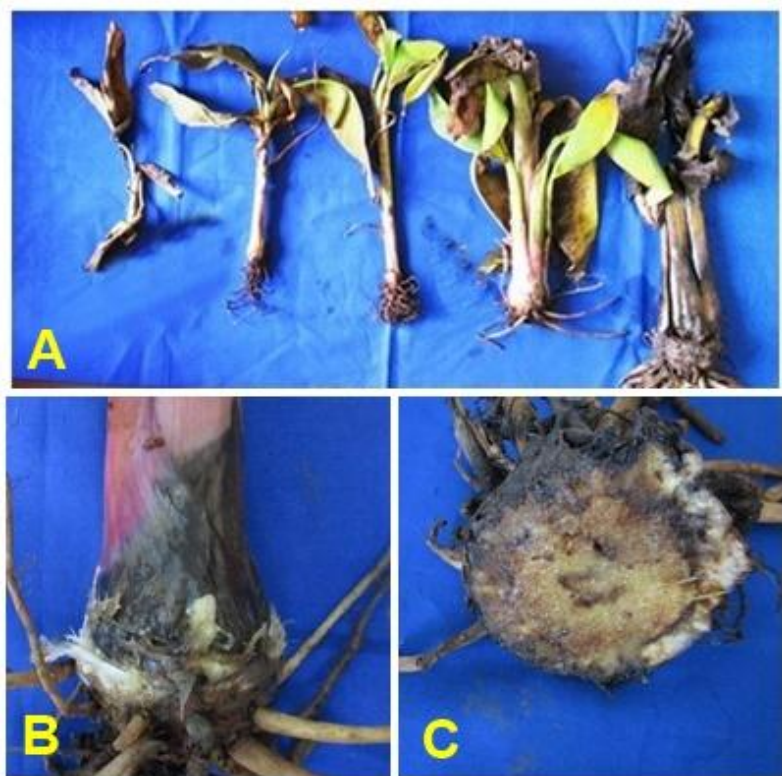

A - different stages of rotting of 1-3 months old plants, B - Initial rotting of collar region of pseudostem, C Completely rotten rhizome

Fig.2 Effect of temperature on growth of bacterial isolates

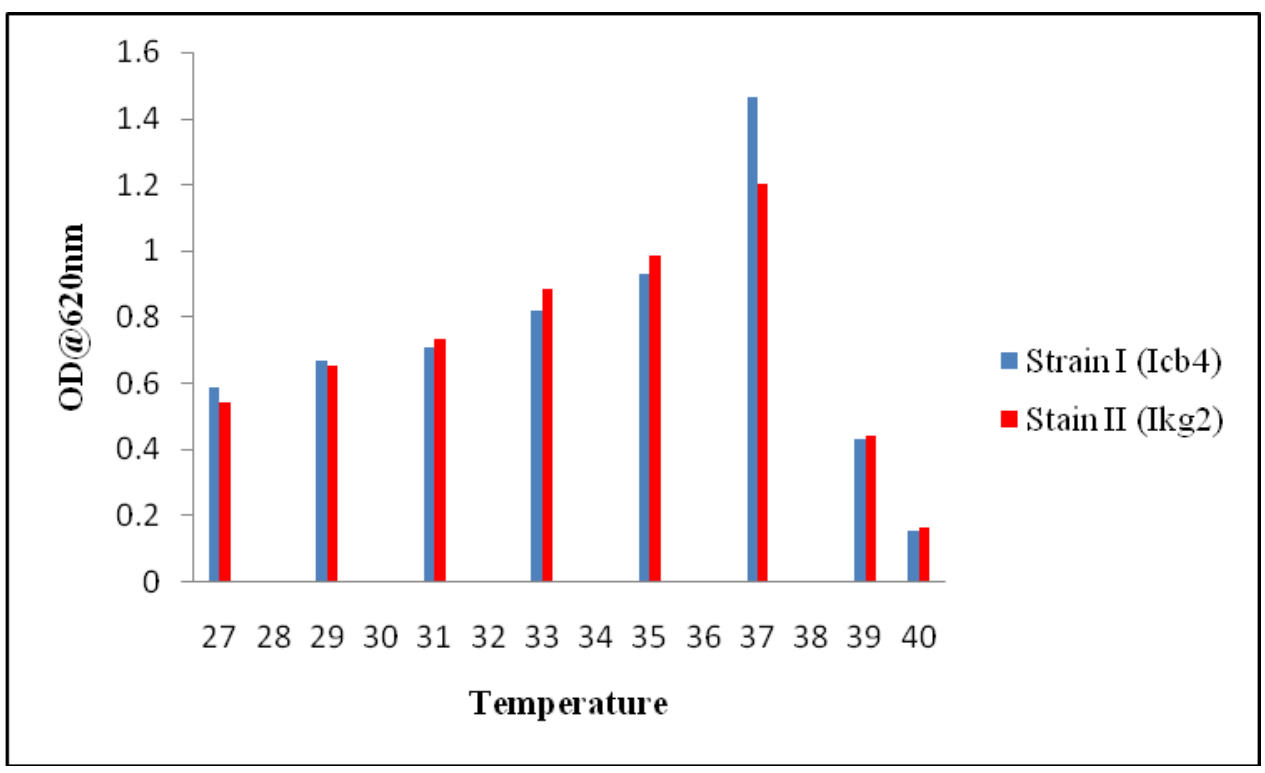


Fig.3 PCR on isolates $\mathrm{Ikg}_{2}$ and $\mathrm{Icb}_{4}-$ Amplification of $16 \mathrm{~S}$ rRNA gene using $27 \mathrm{~F}$ and $1492 \mathrm{R}$ primers

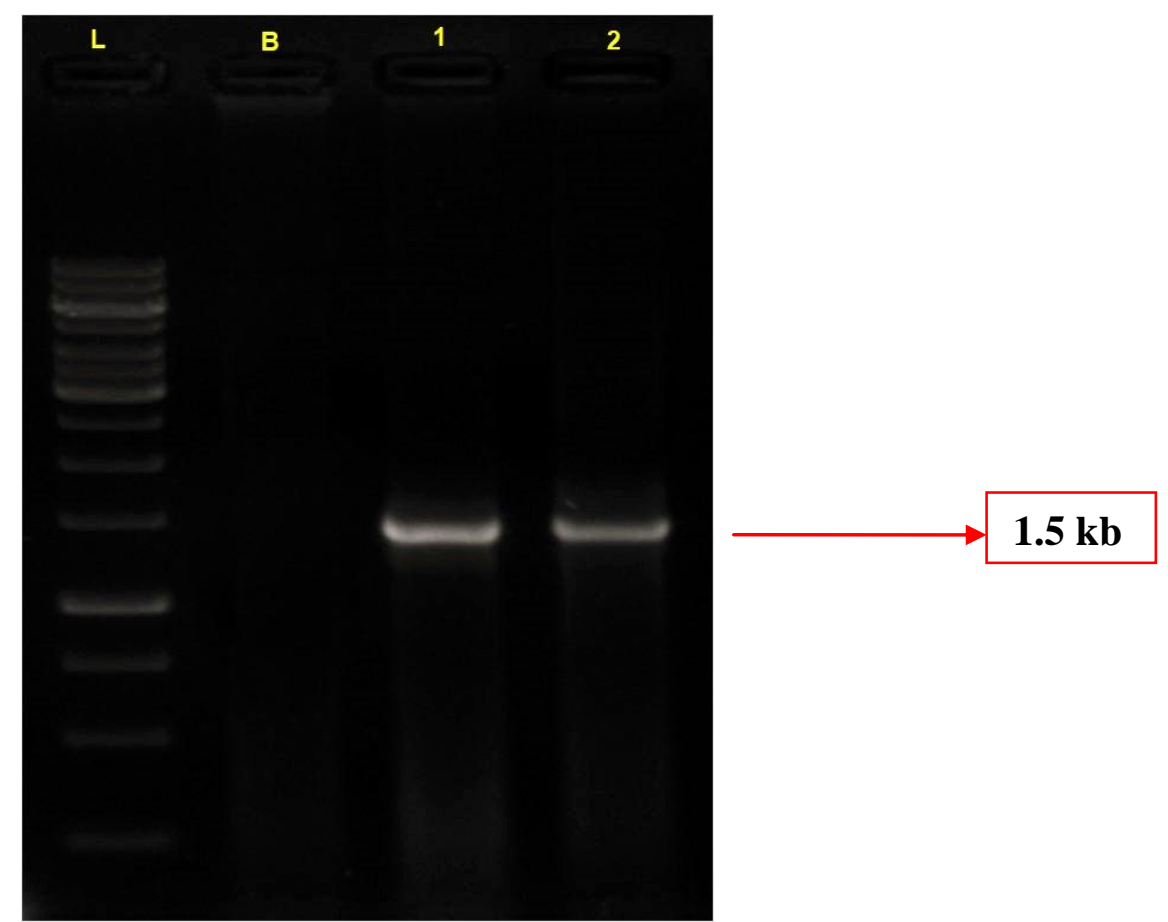

L - $1 \mathrm{~Kb}$ plus ladder, B - control, 1 and 2 - Amplified colony PCR product of bacterial isolates

Fig.4 Phylogenetic tree of partial 16S rRNA gene sequences of $P$. carotovorum subsp carotovorum isolated from Banana. Sequences of selected references strains are included

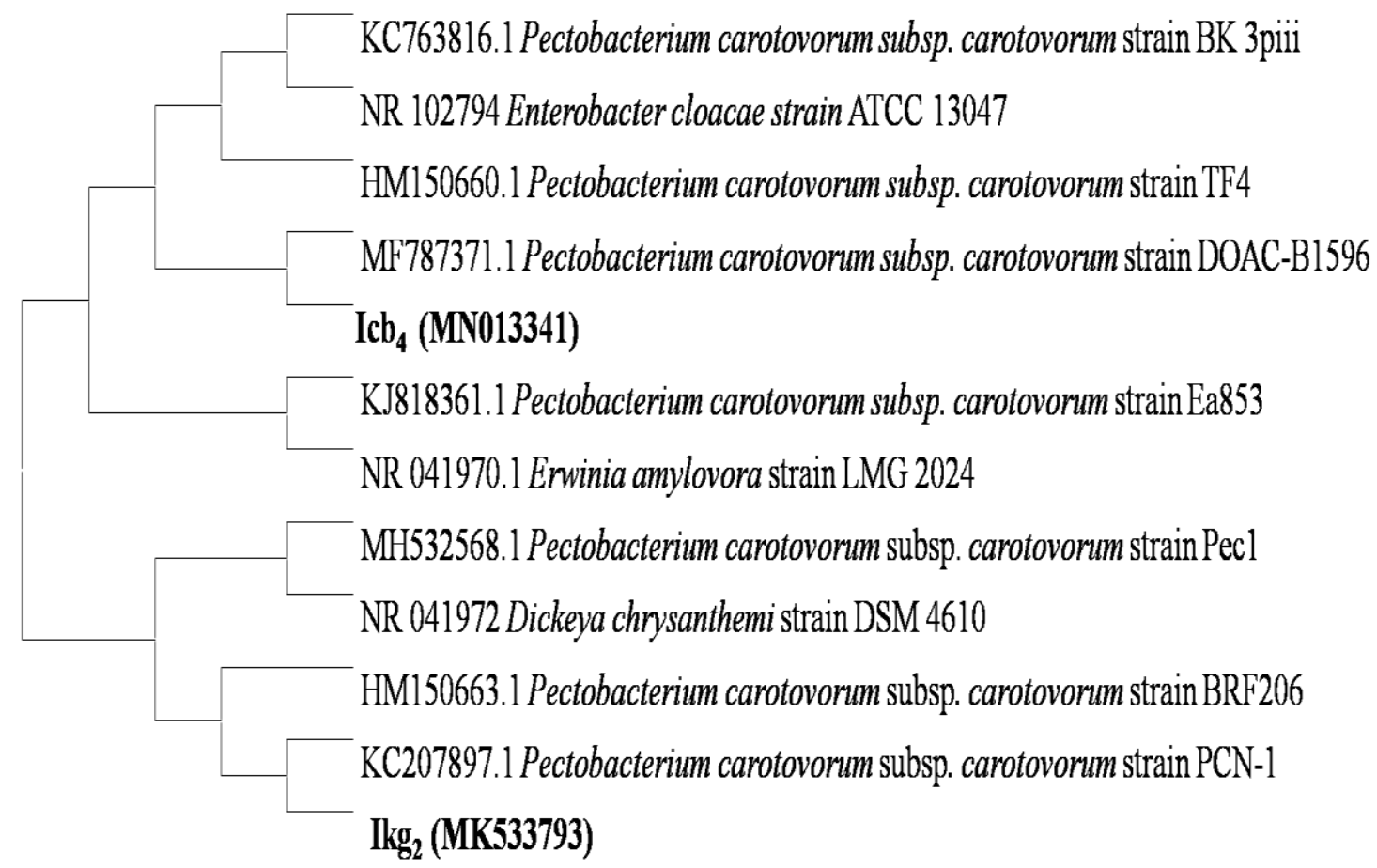


The length of the bacterium was in the range of 2.3-2.7 $\mu \mathrm{m}$ and width in the range of 0.6$0.9 \mu \mathrm{m}$. The flagella Stain give a method for viewing bacterial flagella. Peritrichous nature of the flagella was observed through flagella staining.

The results of biochemical tests revealed that isolates $\mathrm{Icb}_{4}$ and $\mathrm{Ikg}_{2}$ have a positive reaction for Pectate degradation, Pits formation on CVP medium, Growth at $36-37^{\circ} \mathrm{C}$, Motility test, Nitrate reductase, Catalase, $\mathrm{H}_{2} \mathrm{~S}$ production, Methyl red and Caesin hydrolysis and a negative reaction for Urease production, Oxidase test, Indole test and Gelatin liquefaction. Bacterial growth was observed in the inoculated peptone broth containing three and four per cent sodium chloride. Results showed that the isolates $\mathrm{Ikg}_{2}$ and $\mathrm{Icb}_{4}$ tolerate the salt at all the concentration. Salt tolerant nature of Pectobacterium was previously reported by Dickey (1979), Gomez-Caicedo et al., (2001), Akbar et al., (2015) and Rafiei et al., (2015).

After 5 days of incubation, bacterial cultures inoculated on CVP medium produced characteristic fissures or depressions due to pectate degradation as reported by Cupples and Kelmen (1974), Ma et al., (2007) and Snehalatharani and Khan (2010). Pectobacterium spp. proven to have the pectate degrading ability (Bhupendra and Yogendra, 2015), similarly, in the present study the isolates $\mathrm{Ikg}_{2}$ and $\mathrm{Icb}_{4}$ were found to degrade the sodium polypectate present in the CVP medium, leading to the formation of fissures in five days. Bacterial isolates were insensitive to erythromycin but sensitive to streptomycin. An inhibition zone was observed around the filter paper disc containing streptomycin solution whereas no inhibition zone was observed around the filter paper disc containing erythromycin. $P$. carotovorum is reported to be resistant to erythromycin and susceptible to streptomycin
(Dickey and Victoria, 1980; Snehalatharani and Khan, 2010; Nagrale et al., 2013; Akbar et al., 2015). Since the isolates in this study are resistant to erythromycin and susceptibility to streptomycin, it is confirmed that they belong to Pectobacterium carotovorum.

After $48 \mathrm{~h}$ of incubation, the maximum growth of bacteria was recorded at $37{ }^{\circ} \mathrm{C}$ (OD@620nm value 1.465 and 1.204) followed by growth at $35{ }^{\circ} \mathrm{C}$ (OD@620nm value 0.931 and 0.988) in isolates $\mathrm{Icb}_{4}$ and $\mathrm{Ikg}_{2}$ (Table 5, Fig. 2). A previous study by De Boer and Kelman (2001), also reports that $E$. carotovora subsp. carotovora can grow at 37 ${ }^{\circ} \mathrm{C}$ while E. carotovora subsp. atroseptica fails to grow at such a high temperature. The temperature of $30^{\circ} \mathrm{C}$ and above is most favourable and destructive for the development of soft rot caused by $E$. carotovora sub sp. Carotovora. Similarly, Smadja et al., (2004) demonstrated that all multiplication of eight strains of E. carotovora was high and able to grow up to $37^{\circ} \mathrm{C}$. The temperature range $20-35^{\circ} \mathrm{C}$ enhanced the rotting ability of E. carotovora subsp carotovora was previously reported by Raju et al., (2008), Bhat et al., (2010) and Raan et al., (2012).

\section{DNA amplification and polymerase chain reaction (PCR)}

The 16S rRNA universal primers were used to amplify DNA fragment enzymatically by polymerase chain reaction (PCR). The primer set which has a sequence 27F (5'AGAGTTTGATCCTGGCTCAG-3 and 1492R- (5'-GGTTACCTTGTTACGACTT$\left.3^{\circ}\right)$, during the electrophoresis process within (one and a half) hour, the results showed that selected isolates $\mathrm{Icb}_{4}$ and $\mathrm{Ikg}_{2}$ has yielded markers at $1.5 \mathrm{~kb}$ (Fig. 3). The BLAST analysis of nucleotide sequence had more than 99\% similarity with existing isolates of Pectobacterium carotovorum subsp. 
Carotovorum in NCBI. The nucleotide sequence of our isolates submitted in NCBI database, bearing Acc. No. MK533793 and MN013341. The phylogenetic tree constructed using the 16S rRNA gene sequences of bacterial pathogen and including representative bacterial type strains of related taxa generated by the neighbour-joining method in MEGA 6.0 (Fig. 4). Sequence analysis of $16 \mathrm{~S}$ rRNA gene sequences indicated that the strains $\mathrm{Ikg}_{2}$ and $\mathrm{Icb}_{4}$ was homologous with Pectobacterium carotovorum subsp. carotovorum strain PCN1 and strain DOAC-B1596 and were also closely related to Pectobacterium carotovorum subsp. carotovorum strain BRF206. In a similar study, Zhu et al., (2010) reported that the length of the $3216 \mathrm{~S}$ rRNA sequences of almost all isolates was $1381 \mathrm{bp}$, it has at least a 98\% nucleotide sequence similarity with those of other Pectobacterium strains present in GenBank. Thapa et al., (2011) had constructed a phylogenetic tree of Pectobacterium species and reported that $P$. carotovorum subsp. Carotovorum is closer with $P$. carotovorum subsp. oderiferum. Caruso et al., (2016) stated that the analysis of the 16S rRNA gene sequence revealed that the isolates from tomato belong to $P$. carotovorum subsp. carotovorum and $P$. carotovorum. subsp. brasiliensis, respectively.

Characterization of bacterial isolates was analyzed through Pathogenicity test followed by cultural, morphological, biochemical and physiological methods. Through molecular characterization, a bacterium was confirmed at the subspecies level, P. carotovorum Ssp. carotovorum. The phylogenetic tree constructed with the 16S rRNA sequences had discriminated the pathogen clearly.

\section{Acknowledgement}

The authors thank the financial support provided by the Department of Science and
Technology (FIST), Government of India, New Delhi for accomplishing this work.

\section{References}

Akbar, A., Ahmad, M., Azra, Neelam, Khan, S. Z. and Ahmad, Z. 2015. Characterization of the Causal organism of soft rot of tomatoes and other vegetables and evaluation of its Most aggressive isolates. Am. J. Plant Sci. 6, 511-517.

Bhat, K.A., Masoodi, S.D., Bhat, N.A., Ahmad, M. Zargar, M.Y. Mir, S. A. and Ashraf Bhat, M. 2010. Studies on the effect of temperature on the development of soft rot of cabbage (brassica oleracea var. Capitata) caused by erwinia carotovora sub sp. Carotovora. J. phytol. 2(2): 64-67.

Bhupendra, S. and Yogendra, S., 2015. Characterization of Erwinia chrysanthemi isolates inciting Stalk rot disease of sorghum. Afr. J. Agric. Res. 10 (22), 2309-2314.

Caruso1, A. Licciardello, G. La Rosa1, R. Catara, V. and Bella P. 2016. Mixed infection of Pectobacterium carotovorum subsp. carotovorum and P. carotovorum subsp. brasiliensis in tomato stem rot in Italy. J. Pl. Pathol., 98 (3): 661-665

Cuppels, D. and Kelman, A.1974. Evaluation of selective media for isolation of softrot Bacteria from soil and plant tissue. Phytopathol., 64 (4), 468-475.

Czajkowski, R., Grzegorz, G. and van der Wolf, J. 2009. Distribution of Dickeya spp. and Pectobacterium carotovorum ssp. Carotovorum in Naturally Infected Seed Potatoes. E. J. Pl. Pathol., 125, 263-275.

De Boer, S.H.and Kelman, A. 2001. Gram Negative Bacteria: Erwinia Soft rot Group In: N.W. Schaad, J.B. Jones \& W. Chun (Eds.), Laboratory guide for 
the identification of plant Pathogenic bacteria. 3rd Edn St. Paul: APS Press. Pp. 56-72.

d'Hont, A., Denoeud, F., Aury, J. M., Baurens, F. C., Carreel, F., Garsmeur, O., Noel, B., Bocs, S., Droc, G., Rouard, M., Da Silva, C., Jabbari, K., Cardi, C., Poulain, J., Souquet, M., Labadie, K., Jourda, C., Lengellé, J., Rodier-Goud, M., Alberti, A., Bernard, M., Correa, M., Ayyampalayam, S., McKain, M. R., Leebens-Mack, J., Burgess, D., Freeling, M., Mbéguié-a-Mbéguié, D., Chabannes, M. 2012. "The banana (Musa acuminata) genome and the evolution of monocotyledonous plants". Nature. 488(7410): 213-7.

Dickey, R. 1979. Erwinia chrysanthemi: a comparative study of phenotypic properties of Strains from several hosts and other Erwinia species. Phytopathol., 69 (4), 324-329

Dickey, R. and Victoria, J., 1980. Taxonomy and emended description of strains of Erwinia Isolated from Musa paradisiaca L. Int. J. Syst. Bacteriol. 30 (3), 129-134.

Doolotkeldieva, T., Bobusheva, S. and Suleymankisi, A. 2016. Biological control of Erwinia Carotovora ssp. Carotovora by Streptomyces species. Adv. Microbiol. 6 (02), 104-114

Du Raa, S. Coutinho, T. A. and Van der Waals, J. E. 2016. Cardinal temperature differences, determined in vitro, between closely related species and subspecies of pectinolytic bacteria responsible for blackleg and soft rot on potatoes. Eur. J. Plant Pathol. 144:361-369.

Fiori M, Virdis S, Schiaffino A. 2005. Phenotypic and genetic characterization of Erwinia carotovora ssp. Carotovora (Jones) Bergey et al., Isolates from grafted tomato in
Sardinia, Italy. Phytopathol. Mediterr. 44:50-57.

Gomez, K.A., Gomez, A.A., 1984. Statistical Procedure for Agricultural Research. John Wiley and Sons, IRRI, 1984, New York, pp. 680.

Gomez-Caicedo, L.E., Cheverry, N.E. and Gonzalez, R.S. 2001. Evaluation of cultural, chemical And biological control of vascular rot and wilt in plantain (Musa AAB Simmonds). Infomusa 10, 17-20.

Kado, C.I. 2006. Erwinia and related genera. Prokaryotes 6, 443-450.

Kang, H., Knwon, S. and Go, S. 2003. PCRBased Specific and Sensitive Detection of Pectobacterium carotovorum ssp. Carotovorum by Primers Generated from URP-PCR Finger PrintingDerived Polymorphic Band. Plant Pathol., 52,

Kim, M.H., Cho, M.S., Kim, B.K., Choi, H.J., Hahn, J.H., Kim, C., Kang, M.J., Kim, S.H. and Park, D.S. 2012. Quantitative real-time polymerase chain reaction assay for detection of Pectobacterium wasabiae using YD repeat protein gene-based primers. Plant dis., 96(2), pp.253-257.

Kwon, S.W., Cheun, M.S., Kim, S.H. and Lim, C.K. 2000. Phylogenetic analysis of Pectobacterium species using the 16S-23S rRNA inter-spacer regions. Plant Pathol. J. 47, 1061-1067.

Lelliott, R., Billing, E. and Hayward, A. 1966. A determinative scheme for the fluorescent Plant pathogenic pseudomonas. J. Appl. Bacteriol. 29 (3), 470-489.

Ma, B., Hibbing, M., Kim, H., Reedy, R., Yedidia, I., Breuer, J., Breuer, J., Glasner, J., Perna, N., Kelman, A. and Charkowski, A. 2007. Host range and molecular phylogenies of the soft rot enterobacterial genera Pectobacterium and Dickeya. Phytopathol., Pp. 97. 
Meng, X., Chai, A., Shi, Y., Xie, X., Ma, Z. and $\mathrm{Li}, \mathrm{B} .2017$. Emergence of bacterial soft rot in cucumber caused by Pectobacterium carotovorum subsp. brasiliense in China. Plant dis, 101(2), pp.279-287.

Nabhan, S., De Boer, S. H., Maiss, E., and Wydra, K. 2012. Taxonomic relatedness between Pectobacterium Carotovorum subsp. Carotovorum, Pectobacterium Carotovorum subsp. Odoriferum and Pectobacterium Carotovorum subsp. Brasiliense subsp. Nov. J. Appl. Microbiol. 113, 904-913. Nagaraj, M.S., Kumar, M.R.R., Umashankar, N. and Jayaramaiah, R. 2013. Efficacy of antibiotics and bactericides on the management of 'tip-over' disease of banana. Glob. J. Biosci. Biotechnol. 2 (3), 321-325.

Nagrale, D.T., Borkar, S.G., Gawande, S.P., Mandal, A.K. and Raut, S.A. 2013. Characterization of a bacterial collar and rhizome rot of banana (Musa paradisiaca) Caused by strains of Erwinia chrysanthemi pv. Paradis. J. Appl. Nat. Sci. 5 (2), 435-441.

Ploetz, R.C., Thomas, J.E. and Slabaugh, W.R. 2003. Disease of tropical Fruit crops. Wallingford, UK: CABI Publishing. Pp. 73-134

Rafiei, S., Khodakaramian, G. And Baghaee Ravari, S. 2015. Characterization of Pectobacterium species isolated from vegetable crops in north-west of Iran. Afr. J. Agric. Res. 10 (46), 4258-4267.

Raju, M.R.B., Pal, V. and Jalali, I. 2008.Inoculation Method of Pectobacterium carotovorum sub-sp. Carotovorum and Factors Influencing Development of Bacterial Soft Rot in Radish. J. Mycol. Pl. Pathol. 38(2):311-315.

Schillingford, C.A. 1974. Bacterial rhizome rot of banana in Jamaica. Plant Dis. Rep. 58, 214-218.
Seo ST, Furuya N, Lim CK, Takanami Y, Tsuchiya K. 2002. Phenotypic and genetic diversity of Erwinia carotovora ssp. Carotovora strains from Asia. J Phytopathol. 150:120-127

Shrestha, R., Lee, S., Hur, J., Lim, C.2005. The effects of temperature, $\mathrm{pH}$, and bactericides on the growth of Erwinia pyrifoliae and Erwinia amylovora. Plant Pathol. J. 21 (2), 127-131.

Skerman, V.B.D. 1967. "A Guide to the identification of the Genera $\mathrm{mf}$ Bacteria". 2nd edition. Baltimore, Maryland, Williams and Wilkins.

Smadja, B., Latour, X., Trigui, S., Burini, J. F., Chevalier, S. and Orange, N. 2004. Thermo dependence of growth and enzymatic Activities implicated in pathogenicity of two Erwinia Carotovora subspeciess (Pectobacterium spp.). Can. J. Microbiol. 50, 19-27.

Snehalatharani, A. and Khan, A. 2010. Biochemical and physiological characterisation of Erwinia species causing tip-over disease of banana. Arch. Phytopathol. Plant Prot. 43 (11), 1072-1080.

Thammaiah, N., V.C. Kanamadi, A.M. Shirol, P.M. Gangadharappa and M.S. Kulkarni.2005c. Incidence of bacterial rhizome rot of banana in northern Karnataka and in-vitro evaluation of chemicals, antibiotics, and plant extracts against Erwinia chrysanthemi causing rhizome rot or tip over disease of banana. National Seminar on Integrated production and post harvest management of Tropical Fruits held at Bidhan Chandra Krishi Viswavidyalaya, Mohanpur, pp. 58

Thangavelu, R. 2009. Management of fungal and bacterial diseases in micropropagated plants. In: 2nd Natl Conf Banana. Jalgaon, Maharashtra, India, pp 101-107 
Thapa, S.P., Park, H.R., Lim, C.K. and Hur, J.H. 2011. Phylogeny of the Korean Erwinia Species as determined by comparison of $16 \mathrm{~S}$ rDNA sequences. J. Agric. Life Environ. Sci. 23 (4), 6269.

Thomas, P., Swarna, G., Patil, P. and Rawal, R. 2008. Ubiquitous presence of normally nonculturable Endophytic bacteria in field shoot-tips of banana and their gradual activation to quiescent cultivable form in tissue cultures. Plant Cell Tiss. Org. Cult. 93 (1), 39-54.

Togashi, J. 1988. Identification of the organisms causing the soft rot disease in vegetables in the fields of Tsuruaka district. Bull. Yamaga Univ. Agric. Sci. 10 (3), 473-478.

Usha, N. 2003. Etiology and Management of Rhizome Rot Disease of Banana (M.Sc. (Ag.) Thesis). Kerala Agricultural University, Thrissur, India, pp. 130.

Wen-ping Chen and Tsong-teh Kuo. 1993. A simple and rapid method for the preparation of gramnegative Bacterial genomic. Nucleic Acids Res. 21, Pp. 9.

Zhu, L., Xie, H., Chen, S. and Ma, R. 2010. Rapid isolation, identification and phylogenetic analysis of Pectobacterium carotovorum ssp. J. Plant Pathol., 92(2), pp. 479-483.

\section{How to cite this article:}

Ragavi, G., M. Muthamilan, S. Nakkeeran, N. Kumaravadivel, U. Sivakumar and Suganthi, A. 2019. Molecular Detection of the Causative Agent of Soft Rot (Pectobacterium carotovorum subsp carotovorum) in Banana (Musa sp.). Int.J.Curr.Microbiol.App.Sci. 8(11): 1854-1868. doi: https://doi.org/10.20546/ijcmas.2019.811.218 